J.Edu.\&Sci. , The first conference on Biology, (September-2007)

\title{
Isolation and Characterization of Salt Tolerant Strains of Sinorhizobium meliloti
}

\section{Raad Hassani Sultan \\ Dept. of Biology/ College of Education/ University of Mosul}

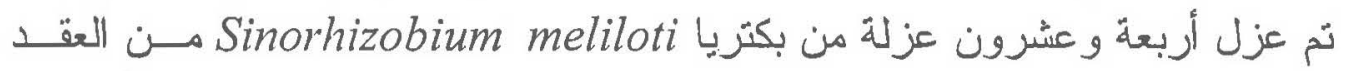

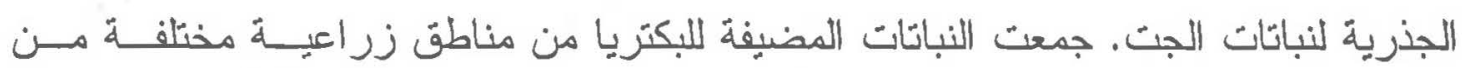

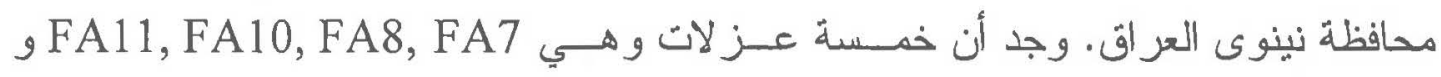

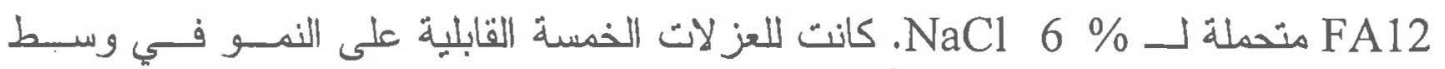

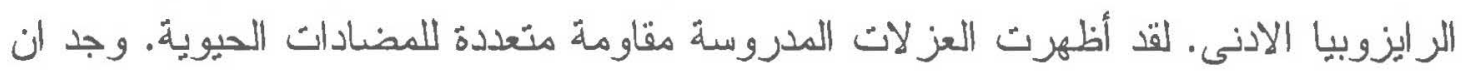

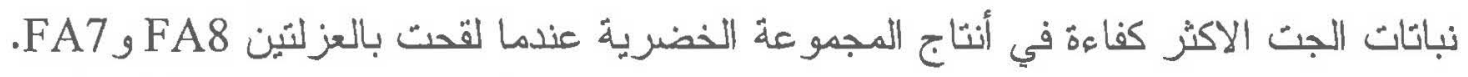

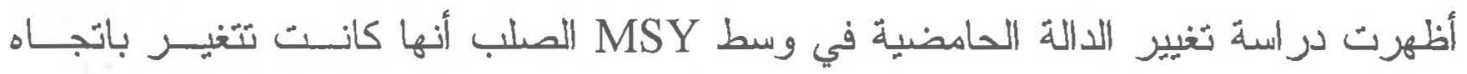

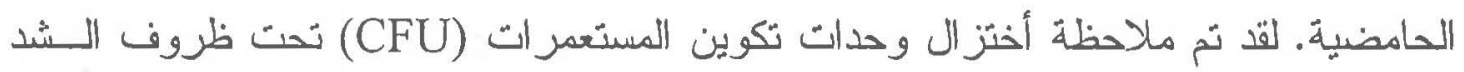

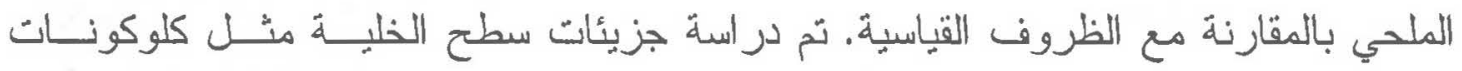

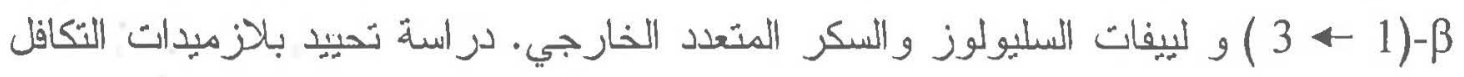

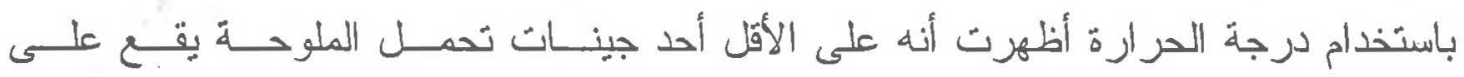
البلازميدات التعايشية.

\section{ABSTRACT}

Twenty four strains of Sinorhizobium meliloti were isolated from root nodules of alfalfa plants. Host plants collected from different agroclimatic regions of Ninavah province-Iraq. Five strains, vis. FA7, FA8, FA10, FA11 and FA12 were found tolerant to $6 \% \mathrm{NaCl}$. All the five strains were able to grow on rhizobial minimal medium. The five studied strains showed multiple antibiotic resistance. The more sufficient production in shoot group in alfalfa plants found when the plants inoculated with FA8 and FA7 strains. pH changes in MSY solid medium study revealed that changes in $\mathrm{pH}$ towards acidity. Reduction in colony forming units (CFU) was observed under salt conditions in comparison with normal conditions. Production of cell surface molecules in these five strains , such as, $\beta-(1 \longrightarrow 3)$ glucans, cellulose fibrils and exopolysaccharides were also studied. Heat curing of Sym plasmids study revealed that at least one of the salt tolerant genes lays on Sym plasmids.

Presented at the first conference on Biology, University of Mosul ,college of Education, 4-5 September 2007 


\section{Introduction}

Atmospheric $\mathrm{N}_{2}$ fixed symbiotically by the association between Rhizobium species and legumes represents a renewable source of $\mathrm{N}$ for agriculture (1). Soil salinity is a major limiting nitrogen fixation factor because of its adverse effects on the growth of the host plant, on its root nodule bacteria and on symbiotic development (2). Rhizobia vary in efficacy of osmoregulation-response to salt stress $(3,4,5)$. This capacity of adaptation of the microbial population was exhibited in a study of the survival of Bradyrhizobium japonicum in sludge-amended soils (6). Some salinity tolerant rhizobia were reported which showed better nodulation and nitrogen fixation than salinity sensitive rhizobia under saline conditions (7). Though these salt tolerant strains seem to accumulate osmoprotectants such as glycine betaine, proline betaine glutamic acid etc., the biochemical mechanisms of salt tolerance is not fully understood (5).

Several cell surface molecules like exopolysaccharides and $\beta-(1 \rightarrow 2)$ cyclic glucans, which play a role in early stages of infection process also play a role in stress tolerance. $\beta-(1 \rightarrow 2)$ glucan has been found to play a major role in osmotic adaptation (8). Nogales et al. (9) identified eight gene loci required for adaptation to high external $\mathrm{NaCl}$. Seven different genes involved in salt tolerance were isolated and characterized from S. meliloti mutants (10). Miller-Williams et al. (11) studied the determinants necessary for adaptation to high $\mathrm{NaCl}$ concentrations and they isolated salt-sensitive mutants of $S$. meliloti strain Rm1021. Payakapong et al. (12) identified two clusters of genes involved in salt tolerance in Sinorhizobium sp. strain BL3. Bacem et al. (13) isolated salt tolerant rhizobia from a Tunisian oasis that are highly effective for symbiotic $\mathrm{N}_{2}$ fixation.

Selection of salt tolerant and efficient strains is very useful as the selected strains can be introduced into soils of respective stress where competition from naturally occurring rhizobia is lacking. Keeping these observations in mind, the present work was taken for collection of a number of strains of rhizobia from different agroclimatic regions of Ninavah State/ Iraq, selection of stress tolerant strains in the laboratory as well as to characterize these strains for their symbiotic performance and other features. 


\section{Materials and Methods}

\section{Bacterial strains}

Twenty four strains of Sinorhizobium meliloti were isolated from root nodules of alfalfa plants. The plants were collected from different agroclimatic locations of Ninavah State/ Iraq.

\section{Host plant cultivar}

The seeds of alfalfa were obtained from local market.

\section{Media}

3.1. Mannitol Salt Yeast Extract (MSY) Medium (14), (g/l) : mannitol, 10; yeast extract, $0.2 ; \mathrm{K}_{2} \mathrm{HPO}_{4}, 0.2 ; \mathrm{KH}_{2} \mathrm{PO}_{4}, 0.2 ; \mathrm{MgSO}_{4} .7 \mathrm{H}_{2} \mathrm{O}, 0.1$ and $\mathrm{CaCl}_{2} .2 \mathrm{H}_{2} \mathrm{O}, 0.05, \mathrm{pH}$ was adjusted to 6.8 . This medium was used for growing and maintenance of rhizobial strains.

3.2. Yeast Extract Mnnitol (YEM) Medium (15), (g/li) : mannitol, 10; yeast yxtract, $10 ; \mathrm{K}_{2} \mathrm{HPO}_{4}, 0.5 ; \mathrm{MgSO}_{4} .7 \mathrm{H}_{2} \mathrm{O}, 0.2$ and $\mathrm{NaCl}, 0.1$, $\mathrm{pH}$ was adjusted to 6.8. This medium was used for testing succinylated exopolysaccharides, cyclic $\beta-(1 \rightarrow 3)$ glucans, cellulose fibrils production as well as for symbiotic plasmids heat curing study.

3.3. Tryptone Yeast Extract (TY) Medium (16), (g/li) : tryptone, 5.0; yeast extract, 3.0 and $\mathrm{CaCl}_{2} .2 \mathrm{H}_{2} \mathrm{O}, 0.12, \mathrm{pH}$ was adjusted to 7.0 . This medium was used for testing motility. TY swarm plates contained $0.3 \%$ (w/v) agar (17). This medium was also used for symbiotic plasmids heat curing study.

3.4 Rhizobial Minimal Medium (RMM) (18):

Solution A, (g/l) : $\mathrm{Na}_{2} \mathrm{HPO}_{4} .12 \mathrm{H}_{2} \mathrm{O}, 0.45 ;\left(\mathrm{NH}_{4}\right)_{2} \mathrm{SO}_{4}, 2.0 ; \mathrm{FeCl}_{3}$, 2.0; $\mathrm{MgSO}_{4} .7 \mathrm{H}_{2} \mathrm{O}, 0.1$ and $\mathrm{CaCl}_{2} .2 \mathrm{H}_{2} \mathrm{O}, 0.04$. This solution, after adjusting its $\mathrm{pH}$ to 7.0 , was autoclaved.

Solution B: This solution, contains glucose $(20 \%)$ in distilled water, was filter sterilized.

To prepare 1.01 of RMM, $10 \mathrm{ml}$ of solution B was added to $990 \mathrm{ml}$ solution A. This medium was used for testing auxotrophs of rhizobial salt tolerant strains.

3.5. Nitrogen free (NF) Plant Medium (19), (g/l) : $\mathrm{CaCl}_{2}, 132$; $\mathrm{MgSO}_{4} .7 \mathrm{H}_{2} \mathrm{O}, 120 ; \mathrm{KH}_{2} \mathrm{PO}_{4}, 100 ; \mathrm{Na}_{2} \mathrm{HPO}_{4} .2 \mathrm{H}_{2} \mathrm{O}, 150 ;$ Fe-citrate, $0.05 ; \mathrm{MnSO}_{4} .2 \mathrm{H}_{2} \mathrm{O}, 0.11 ; \mathrm{CuSO}_{4} .5 \mathrm{H}_{2} \mathrm{O}, 0.025 ; \mathrm{ZnSO}_{4} .7 \mathrm{H}_{2} \mathrm{O}, 0.28$; $\mathrm{CoCl}_{2} .6 \mathrm{H}_{2} \mathrm{O}, 0.024 ; \mathrm{H}_{3} \mathrm{BO}_{3}, 0.062$ and $\mathrm{NaMoO}_{4} .2 \mathrm{H}_{2} \mathrm{O}, 0.024$. $\mathrm{pH}$ was adjusted to 6.0. This medium was used for authentication and symbiotic response of salt tolerant strains. 


\section{Maintenance of rhizobial strains}

Purified isolated strains were streaked on slants of MSY solid medium. After a growth period of $24-48$ hours at $28 \pm 2{ }^{\circ} \mathrm{C}$, slants were stored at $4{ }^{\circ} \mathrm{C}$ in a refrigerator. Reculturing of rhizobial strains was done each two months.

\section{Supplements to media}

\subsection{Antibiotics}

Five antibiotics with four concentrations, viz., 100, 200, 300 and $400 \mu \mathrm{g} / \mathrm{ml}$ were used in this study. Stock solutions of tetracycline hydrochloride $(\mathrm{Tc})$, chloramphenicol $(\mathrm{Cm})$ and ampicillin $(\mathrm{Am})$ were prepared in ethanol, while streptomycin sulphate $(\mathrm{Sm})$ solution was prepared in distilled water. Nalidixic acid (Nal) was dissolved in $0.05 \mathrm{~N}$ sodium hydroxide. Antibiotic solutions were sterilized by passing them through $0.45 \mu \mathrm{m}$ membrane filters and stored at $4{ }^{\circ} \mathrm{C}$. Different concentrations of antibiotic were added to the autoclaved medium after cooling it to $50^{\circ} \mathrm{C}$, just before plating (20).

\subsection{Salt}

Sodium chloride was added to the medium before autoclaving. Percentage concentration method $(\%, w / v)$ was followed for supplementing this salt into the medium.

\subsection{Dyes}

Aniline blue for cyclic $\beta-(1 \rightarrow 3)$ glucans production or calcoflour white for testing succinylated exopolysaccharides was added to the YEM medium at the rate $0.02 \%(\mathrm{w} / \mathrm{v})$, while congo red for testing cellulose fibrils production was added to the same medium at $0.1 \mathrm{mg} / \mathrm{ml}$ final concentration. Each of these reagents was added to the medium before autoclaving (17).

\section{$5.4 \mathrm{pH}$ indicator dye}

Bromothymol blue dye was added to the MSY solid medium for the $\mathrm{pH}$ changes study at the rate of $2.5 \mathrm{mg} / 100 \mathrm{ml}$ medium before autoclaving (20).

\section{Isolation of rhizobial strains from their host plant}

Vincent (15) procedure was followed for isolating rhizobial strains from the root nodules. Three to four pinkish nodules were washed in distilled water and exposed to $95 \%(\mathrm{v} / \mathrm{v})$ ethanol for 2-4 minutes. These nodules were then washed in sterile distilled water and immersed in 0.1 $\%(\mathrm{w} / \mathrm{v})$ acidified $\mathrm{HgCl}_{2}\left(\mathrm{HgCl}_{2}, 1.0 \mathrm{gm}\right.$; conc. $\mathrm{HCl} 5 \mathrm{ml}$ and water 1.0 liter) for 3-6 minutes. The surface sterilized nodules were washed thoroughly 5-7 times with sterile water to remove traces of mercuric chloride and alcohol. The nodules were then crushed aseptically in $1.0 \mathrm{ml}$ 
sterile saline $(0.85 \% \mathrm{w} / \mathrm{v} \mathrm{NaCl})$ with a sterilized glass rod. Suspension $(0.1 \mathrm{ml})$ was spread on MSY solid medium and the plate was incubated at $28 \pm 2{ }^{\circ} \mathrm{C}$ for $2-4$ days. Transparent mucoid or gummy colonies were picked for further purification.

\section{Screening for salt tolerance}

The growth of all isolated strains of $S$. meliloti was tested by streaking these strains on MSY medium containing (0,2, 4, 6 and $8 \%)$ of $\mathrm{NaCl}$. Incubation was done at $28 \pm 2{ }^{\circ} \mathrm{C}$ for $4-6$ days (21).

\section{Plant inoculation studies}

Alfalfa seeds were sterilized as described by Vincent (15) and transferred onto nitrogen free agar slants in $20 \times 2.5 \mathrm{~cm}$ tubes. Two 2days old seedlings in each tube were inoculated with $10^{8}$ cells (suspended in sterile distilled water) of a particular rhizobial strain. The growth conditions for the plants were 2000 lux light, a photoperiod of $16 \mathrm{hr}$, a dark period of $8 \mathrm{hr}$ and $25^{\circ} \mathrm{C}$ temperature. The morphological features of plants were recorded six weeks after inoculation. For determining the dry plant shoot weight, the plant tops were collected and dried in an oven at $65^{\circ} \mathrm{C}$ for $72 \mathrm{hr}$ and then weighted. Reisolation of bacteria from nodules was done to confirm the nodule occupancy by a particular strain.

\section{Symbiotic plasmids heat curing study}

To emphasize the position of salt tolerance genes whether it lay on chromosome or on symbiotic plasmids, heat curing of Sym plasmids procedure was done as follows: Approximately $10^{10}$ cells from a log phase culture of salt tolerant strain grown on TY medium were evenly spread on the surface of solid YEM medium. The cultures were incubated at $37{ }^{\circ} \mathrm{C}$ for 7 days, during which no growth occurred. The YEM plates were placed at room temperature, and after 5 days, about 100 single colonies arose per plate (22). To confirm symbiotic plasmids curing; plant nodulation test, antibiotic sensitivity and $6 \% \mathrm{NaCl}$ tolerance were done as reported by Vincent (15), Hussein (20) and Sadowsky et al. (21).

\section{Results and Discussion}

\section{Isolation of salt stress tolerating rhizobial strains}

Among studied strains five strains vis. FA7, FA8, FA10, FA11 and FA12 could grow on MSY medium supported with $6 \% \mathrm{NaCl}, 8 \% \mathrm{~K}_{2} \mathrm{SO}_{4}$ and $\mathrm{pH} 4.5$ (data not shown) choosed for further studies. Kumar (23) and Hussein (20) have isolated rhizobial strains from Indian soils which tolerated 4 and $5 \% \mathrm{NaCl}$, respectively. Screening of rhizobial strains for survival and growth in salt stress laboratory media has resulted in some 
success in improving the nodulation of some legumes in stressed soils (24). Tolerance of $S$. meliloti strains to salt stress due to ability of rhizobial cells to accumulate potassium ions inside the cells (25).

\section{Antibiotic resistance patterns of salt tolerant stress}

Results of this study showed that the five $S$. meliloti strains were sensitive to $100 \mu \mathrm{g} / \mathrm{ml}$ of Tc whereas two strains (FA11 and FA12) were able to grow on MSY medium supplemented with $200 \mu \mathrm{g} / \mathrm{ml}$ of $(\mathrm{Cm})$, increasing the concentrations of this antibiotic up to $400 \mu \mathrm{g} / \mathrm{ml}$ resulted in inhibition of growth of all the studied strains. These strains also were resistant to Am up to $400 \mu \mathrm{g} / \mathrm{ml}$. FA10 strain was able to grow with 300 $\mu \mathrm{g} / \mathrm{ml} \mathrm{Sm}$ whereas there is no growth with 300 and $400 \mu \mathrm{g} / \mathrm{ml}$ for all strains. All strains, except FA12 grew on MSY medium supplemented with $\mathrm{Nal}$ up to $400 \mu \mathrm{g} / \mathrm{ml}$. Multiple antibiotic resistances to antibiotics explain existences of these strains in soil and then enter symbiotic relation with their host plant (6). The antibiotic resistance may be helpful in further genetic analysis of salt tolerance in these strains (20).

\section{Test for growth on Rhizobial Minimal Medium (RMM)}

Results of this study revealed that the five studied strains were able to grow on RMM solid medium after 4-5 days incubation period. This result revealed that non of these strains suffered from auxotrophy (26). Such these strains are useful for genetic studies (12).

\section{Symbiotic characteristics of alfalfa plants inoculated with $\mathrm{NaCl}$ tolerant strains}

Results of this study showed that the nodules induced by all the studied strains were pinkish in color and were located on both primary and lateral roots. The nodules were cylindrical in shape except in the strain FA11, the induced nodules were branched (Table 1). The plants inoculated with FA12 strain showed maximum mean shoot lengths $(20.5$ $\mathrm{Cm}$ ). Mean number of days for the appearance of first nodule varied from 7.2 in strain FA12 to 10.1 in strain FA11. The mean number of nodules per plant ranged from 3.5 in strain FA10 to 7.2 in strain FA12. The minimum mean nodule dry weight per plant $(0.4 \mathrm{mg})$ was observed in strain FA10, whereas strain FA12 produced the maximum value $(2.1 \mathrm{mg})$ for this character. The mean shoot dry weights per plant ranged from 18.9 in strain FA10 to $44.1 \mathrm{mg}$ in strain FA8. The more sufficient production in shoot group in alfalfa plants was found when the plants were inoculated with FA8 and FA7 strains, respectively. However, the performance of these strains under salt stress conditions in the field remains to be studied (20). 


\section{Raad Hassani Sultan \& Fawz A. AL- Safar}

Table (1) Symbiotic characteristics of alfalfa plants inoculated with $\mathrm{NaCl}$ tolerant strains of Sinorhiobium meliloti

\begin{tabular}{|c|c|c|c|c|c|c|}
\hline \multirow[t]{2}{*}{ Strains } & \multirow{2}{*}{$\begin{array}{l}\text { Mean } \\
\text { shoot } \\
\text { length }(\mathrm{cm})\end{array}$} & \multirow{2}{*}{$\begin{array}{l}\text { Mean no. } \\
\text { of days to } \\
\text { first } \\
\text { nodule }\end{array}$} & \multicolumn{3}{|c|}{ Nodule characteristics } & \multirow{2}{*}{$\begin{array}{l}\text { Mean } \\
\text { shoot dry } \\
\text { weight } \\
\text { (mg) }\end{array}$} \\
\hline & & & $\begin{array}{l}\text { Mean } \\
\text { no./plant }\end{array}$ & Shape & $\begin{array}{l}\text { Mean } \\
\text { dry wt. } \\
\text { (mg) } \\
\text { /plant }\end{array}$ & \\
\hline FA7 & $17.5^{*} \pm 1.2$ & $8.4 \pm 1.0$ & $4.7 \pm 2.0$ & Cylindrical & $1.3 \pm 0.4$ & $40.5 \pm 2.9$ \\
\hline FA8 & $17.0 \pm 0.5$ & $8.0 \pm 0.5$ & $5.0 \pm 1.4$ & -do- & $1.6 \pm 0.2$ & $44.1 \pm 4.7$ \\
\hline FA10 & $09.9^{4} \pm 1.7$ & $9.3 \pm 1.2$ & $3.5 \pm 1.9$ & -do- & $0.4 \pm 0.2$ & $18.9^{\star} \pm 1.3$ \\
\hline FA11 & $14.5 \pm 0.9$ & $10.1 \pm 0.9$ & $6.0 \pm 1.2$ & Branched & $1.9 \pm 0.1$ & $22.3 \pm 5.1$ \\
\hline FA12 & $20.5 \pm 0.7$ & $7.2 \pm 0.8$ & $7.2 \pm 1.7$ & Cylindrical & $2.1 \pm 0.6$ & $36.0 \pm 0.8$ \\
\hline Control & $5.5 \pm 1.1$ & -...... & -.....-. & -n..... & -..-- & $09.0 \pm 0.2$ \\
\hline
\end{tabular}

* Each value is mean of ten plants, Cont. $=$ control (uninoculated plants), ${ }^{*}$ Difference significantly from the control $(\mathrm{P}<0.05)$,

$\pm=$ Standard deviation (S.D.).

\section{5. $p H$ changes during growth of the $\mathrm{NaCl}$ tolerant strains}

On solid MSY medium containing $6 \% \mathrm{NaCl}$ change to acid $\mathrm{pH}$, as shown by the change of bromothymol blue dye to yellow color, occurred after 48 hours in all $S$. meliloti strains. Only one salt tolerant strain (FA7) changed the $\mathrm{pH}$ to acidic on solid medium under normal condition. Payakapong et al. also obtained colonies from salt tolerance strains of Sinorhizobium sp. showed acidic reactions on YEM agar containing bromothymol blue (12). Howieson (27) reported that during the growth of $S$. meliloti in yeast extract/ sugar preparation, incomplete oxidation of sugars takes place which yields acid end products. But other workers Hernándz and Focht (28); Cadahia et al. (29) found no correlation between growth and $\mathrm{pH}$ changes of the medium in case of cowpea and chickpea rhizobia. The $\mathrm{pH}$ changes during growth seem to be strain $\operatorname{specific}(20)$.

\section{Colony forming units (CFUs) of the $\mathrm{NaCl}$ tolerant strains}

When strains were grown in medium without and with $6 \% \mathrm{NaCl}$, CFU decreased in $6 \% \mathrm{NaCl}$ medium in all strains as compared to that under normal condition (Table 2). Maximum CFU value was $3.3 \times 10 \%$ $\mathrm{ml}$ after $72 \mathrm{hr}$ of incubation under salt stress condition for FA8 strain. Minimum CFU value was $1.4 \times 10^{8} / \mathrm{ml}$ after $24 \mathrm{hr}$ of incubation under salt stress condition for FA10 strain. Under normal condition (without salt stress), maximum CFU value was $4.4 \times 10^{9} / \mathrm{ml}$ after $72 \mathrm{hr}$ incubation for FA8 strain. Minimum CFU under same condition was $2.9 \times 10^{9} / \mathrm{ml}$ after $24 \mathrm{hr}$ incubation for FA10 strain. Other researchers also showed inhibition in growth under salt condition $(12,20)$. 
Table 2. Colony forming units (CFUs) of $\mathrm{NaCl}$ tolerant strains in MSY medium in presence and absence of $6 \% \mathrm{NaCl}$

\begin{tabular}{|c|c|c|c|c|}
\hline Strain & Type of & \multicolumn{3}{|c|}{ CFUs $\times 10^{9} / \mathrm{ml}$ at incubation period (hr) } \\
\cline { 3 - 5 } & condition & 24 & 48 & 72 \\
\hline FA7 & $\mathrm{S}$ & $2.5^{*} \pm 1.3$ & $3.0 \pm 0.4$ & $3.2 \pm 1.1$ \\
& $\mathrm{~N}$ & $3.8 \pm 0.9$ & $4.1 \pm 0.7$ & $4.3 \pm 0.5$ \\
\hline FA8 & $\mathrm{S}$ & $2.4 \pm 0.7$ & $3.2 \pm 2.1$ & $3.3 \pm 0.9$ \\
& $\mathrm{~N}$ & $3.6 \pm 1.1$ & $4.2 \pm 0.6$ & $4.4 \pm 1.2$ \\
\hline FA10 & $\mathrm{S}$ & $1.4 \pm 1.2$ & $1.8 \pm 0.9$ & $1.9 \pm 0.3$ \\
& $\mathrm{~N}$ & $2.9 \pm 0.9$ & $3.5 \pm 0.5$ & $3.3 \pm 0.7$ \\
\hline FA11 & $\mathrm{S}$ & $2.3 \pm 0.5$ & $2.8 \pm 1.3$ & $2.7 \pm 1.1$ \\
& $\mathrm{~N}$ & $3.1 \pm 1.3$ & $4.0 \pm 0.8$ & $4.1 \pm 1.3$ \\
\hline FA12 & $\mathrm{S}$ & $1.7 \pm 0.8$ & $2.5 \pm 0.5$ & $2.3 \pm 0.8$ \\
& $\mathrm{~N}$ & $3.3 \pm 0.6$ & $3.8 \pm 0.9$ & $3.7 \pm 0.6$ \\
\hline
\end{tabular}

$\mathrm{S}=$ Stress condition, $\mathrm{N}=$ Normal condition, ${ }^{*}$ Average of three replicates, $\pm=$ Standard deviation (S.D.).

\section{Production of cell surface molecules under normal and salt stress condition}

Under normal condition the ability to produce cyclic $\beta-(1 \rightarrow 3)$ glucans was present in the all studied strains. This ability increased under salt stress condition (6\%) for the strain FA7 and FA12. Also all the studied strains were able to produce cellulose fibrils and the salt stress conditions have no effect on the production of cell surface molecule in any of the strains. The ability of production of succinylated exopolysaccharide (SEPS) was unaffected by salt stress in studied strains except FA10, where the production increased under salt stress conditions in comparison with normal condition. Swamynathan and Singh (12) reported that the purine auxotrophy has effect on $\beta-(1 \rightarrow 3)$ production.

In this study all the strains were prototroph so the production of these cell surface molecules was normal. Hussein (20) also reported that the salt stress condition has no effect on cellulose fibrils production. Many researchers revealed the role of exopolysaccharide in rhizobium-legume symbiosis especially in initiation and elongation of infection thread when rhizobium invades root hairs of host plants and induce $\mathrm{N}_{2}$ fixing root nodule $(30,31,32)$. Howieson et al. (24) reported that there is no relation between production of exopolysaccharides and stress condition in $S$. meliloti, while in Rhizobium spp. the production of exopolysaccharide increased under stress condition (33).

\section{Motility of $S$. meliloti salt tolerant strains under normal and salt stress conditions}

Higher motility of a rhizobial strains is helpful to it in its competitive ability (17). Results showed that the values of motility of $S$. meliloti salt tolerant strains after $18 \mathrm{hr}$ of inoculation decreased about one 


\section{ل}

fourth in FA8 and FA11 strains under salt stress conditions in comparison with normal conditions (without salt stress) (Table 3).

Salt stress condition resulted in decreasing the motility values in FA10 and FA12 up to one third. Less effect of salt stress was on FA7 strain in comparison with normal conditions, therefore this strain may be used as inoculants under salt stress conditions. Hussein (20) revealed that salt stress has different effect on motility of $S$. meliloti salt tolerant strains.

Table 3. Motility of $S$. meliloti salt tolerant strains growing in MSY medium with and without $6 \% \mathrm{NaCl}$

\begin{tabular}{|c|c|c|}
\hline \multirow{2}{*}{ Strains } & \multicolumn{2}{|c|}{ Motility after 18 hrs of incubation (mm) } \\
\cline { 2 - 3 } & Under normal conditions & Under stress conditions \\
\hline FA7 & $19.4^{*} \pm 4.3$ & $18.6 \pm 3.6$ \\
\hline FA8 & $08.6 \pm 2.5$ & $6.5 \pm 1.0$ \\
\hline FA10 & $10.3 \pm 2.1$ & $6.1 \pm 1.9$ \\
\hline FA11 & $20.5 \pm 3.3$ & $15.4 \pm 2.4$ \\
\hline FA12 & $12.0 \pm 2.9$ & $8.9 \pm 1.7$ \\
\hline
\end{tabular}

* Each value is an average of three replicates, $\pm=$ Standard deviation (S.D.)

\section{Symbiotic plasmids heat curing study}

Results revealed that heat curing of $S$. meliloti salt tolerant strains resulted in Nod phenotype when alfalfa plants inoculated with these strains. Obtained colonies after heat curing of symbiotic plasmids of salt tolerance strains showed sensitivity against $\mathrm{Cm}, \mathrm{Am}, \mathrm{Sm}$ and $\mathrm{Nal}$ antibiotics when the MSY solid medium supplemented with minimum concentration $(100 \mu \mathrm{g} / \mathrm{ml})$ of the mentioned antibiotics. These results mean successful of heat curing of symbiotic plasmids. The loss of Rhizobium nodulation properties strains has been reported from many laboratories (34). Zurkowski (35) isolated many non-nodulating mutants of Rhizobium leguminosarum bv. Trifolii after incubation at an elevated temperature with a high frequency of loss of nodulation properties.

After heat curing of $S$. meliloti salt tolerant strains, growing colonies were recultured on MSY medium supplemented with $6 \% \mathrm{NaCl}$. No visible growth was noticed for the five studied strains. This result revealed that at least one of the salt tolerant genes lay on Symbiotic plasmids. Payakapong et al. (12) identified two gene clusters for salt tolerance in both fast and slow growing rhizobia. 


\section{References}

1. Peoples M. B., Ladha J. K. and Herridge D. F., Plant Soil, 174: 83-101 (1995).

2. Garg B. K., Vankateswarla B., Vyas S. P. and Lahiri A. N., Indian J. Exp. Biol., 22: 511-512 (1984).

3. Busse M. D. and Bottomley P. J., Apll. Environ. Microbiol., 55: 24312436 (1989).

4. Surange S., Wollum A. G., Kumar N. and Nautiyal C. S., Can. J. Microbiol., 43: 891-894 (1997).

5. Zahran H. H., Bil. Fertil. Soils, 25: 211-223 (1997).

6. Tate R. L., "Soil Microbiology III". John Wiley and Sons, Inc., (2000).

7. Bala N., Sharma P. K. and Lakshminarayana K., Agricul. Ecosys. Environ., 33: 33-46 (1990).

8. Dylan T., Helinski D.R. and Ditta G. S. J. Bacteriol., 172: 1400-1408 (1990).

9. Nogales J., Campos R., BenAbdelkhalek H., Olivares J., Lluch C. and Sanjuan J., Molecular Plant-Microbe Intract., 15: 225-232 (2002).

10.Wei W., Jiang J., Li X., Wang L. and Yang S.S., Lett. Appl. Microbiol., 39: 278-283 (2004).

11.Miller-Williams M., Loewen P. C. and Oresnik I. J., Micobiol., 152: 2049-2059 (2006).

12.Payakapong W., Tittabutr P., Teaumroong N., Boonkerd N., Singleton P. W. and Borthakur D., Symbiosis, 41: 47-53 (2006).

13.Bacem M., Moncef M., Gisèle L., Mohammed A. and Ridha M., Arch. Micrbiol., 187: 79-85 (2007).

14. Khanuja S. P. S. and Kumar S., J. Genet., 68: 93-108 (1989).

15. Vincent J. M., "A Manual for the Practical Study of the Root-Nodule Bacteria". Blackwell Scientific Publication Ltd., Oxford, U.K. (1970).

16. Khanuja S. P. S. and Kumar S., J. Exp. Biol., 26: 665-667 (1988).

17. Swamynatha S. K. and Singh A. J. Biosci., 20:17-28 (1995).

18. Singh A., Ram J., Sikka V. K. and Kumar S., J. Exp. Biol., 22: 239247 (1984).

19. Fahraeus G., J. Gen. Microbiol., 16: 374-381 (1957).

20. Hussein I. A., Ph.D. Thesis, University of Roorkee, Roorkee, India (2001). (In English).

21. Sadowsky M. J., Keyser H. H. and Bohlool B. B., Int. J. Sys. Bacteriol., 33: 716-722 (1983).

22.Morrison N. A., Hau C. Y., Trinick M. J., Shine J. and Rolfe B. G., J. Bacteriol., 153: 527-531 (1983).

23. Kumar U., Ph.D. Thesis, University of Roorkee, Roorkee, India (1997). (In English).

24. Howieson J. G., Ewing M. A. and D́Antuono M. F. Plant Soil, 105: 179-188 (1988). 
25. Yelton M. M., Yang S. S., Edie S. A. and Lim S. T., J. Gen. Microbiol., 129: 1537-1547 (1983).

26. Prasad C. K., Vineetha K. E., Hassani R. and Randhawa G. S., J. Exp. Biol., 38: 1041-1049 (2000).

27. Howieson J. G., Plant Soil, 88: 367-376 (1985).

28. Hernández B. S. and Focht D. D., Apll. Environ. Microbiol., 48: 206210 (1984).

29. Cadahia E., Leyva A. and Ruiz-Argüeso T., Arch. Microbiol., 146: 239-244 (1986).

30. Krishnan H. B. and Pueppke S. G., FEMS Microbiol. Lett., 165: 215220 (1998).

31. Cheng H-P. and Walker G. C., J. Bacteriol., 18: 5183-5191 (1998).

32. Pellock B. J., Cheng H-P. and Walker G. C., J. Bacteriol., 182: 43104318 (2000).

33. Cunningham S. D. and Munns D. N., Soil soc. Am. J., 48: 1273-1276 (1984).

34. Beringer J. E. "Plasmid transfer in Rhizobium". Proceedings of the First International Symposium on Nitrogen Fixation. Washington State University Press, Pullman, Washington, U.S.A. (1976).

35. Zurkowski W., J. Bacteriol., 150: 999-1007 (1982). 